Journal of Agricultural Sciences
(Tarim Bilimleri Dergisi)

\title{
Effects of Melatonin on Morus nigra cv. 'Eksi Kara' Exposed to Drought Stress
}

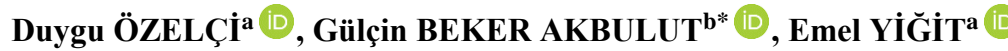

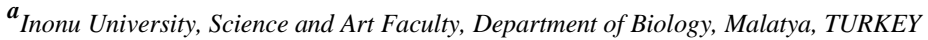

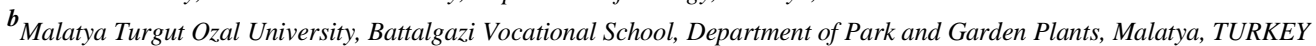

ARTICLE INFO

Research Article

Corresponding Author: Gülçin BEKER AKBULUT, E-mail: gulcin.akbulut@ ozal.edu.tr

Received: 17 June 2021 / Revised: 18 October 2021 / Accepted: 18 October 2021 / Online: 15 October 2022

ÖZELÇi D, AKBULUT BEKER G, YiĞiT E (2022). Effects of Melatonin on Morus nigra cv. 'Eksi Kara' Exposed to Drought Stress. Journal of Agricultural Sciences (Tarim Bilimleri Dergisi), 28(4):555-569. DOI: 10.15832/ankutbd.953558

\section{ABSTRACT}

Today, drought stress threatens the world seriously. Determining the effects of some exogenous stimulators in acquiring resistance against stress will contribute to agriculture under drought stress. In this regard, we investigated the effects of melatonin (MEL) on Morus nigra cv. 'Eksi Kara' (black mulberry) in challenging drought. To reach this object, we reproduced 'Eksi Kara', which is registered in Turkey and has economic importance, in tissue culture by using the meristem culture method. Plants were then transferred in a medium containing polyethylene glycol (PEG) 8000 , which causes $-1.5 \mathrm{MPa}$ drought stress, and $20 \mu 1$ MEL has applied. Leaf samples were taken on the $5^{\text {th }}, 10^{\text {th }}$, and $15^{\text {th }}$ days after treatments in groups of plants grown in a different medium (Control, Control+MEL, PEG and PEG+MEL). The changes in the pigment system, relative water content (RWC) and antioxidant system were evaluated comparatively between the groups to assess plants' growth and determine their roles in coping with stress. Our findings showed that RWC decreased in leaves under drought. Exogenous MEL added in MS medium had a mitigation effect on stress. The reduction was detected in the chlorophyll and carotenoid content of leaves. Moreover, MEL+PEG combination improved the chlorophyll level. It was seen that exogenous MEL application promoted the plant defence mechanism of $M$. nigra plants, which exposed to drought stress, by increasing the accumulation of nonenzymatic antioxidants; total glutathione (GSH), total phenolic, proline) and activities of antioxidant enzymes; catalase (CAT), superoxide dismutase (SOD), Glutathione-S-transferase (GST), glutathione reductase (GR), peroxidase (POD), ascorbate peroxidase (APX). This study also indicates that the application of MEL+PEG composition partially prevented membrane lipid peroxidation by decreasing (malondialdehyde) MDA content.

Keywords: Black mulberry, Malondialdehyde, Pigment, Proline, Relative water Content, Total phenolic

\section{Introduction}

Abiotic stress is the primary cause of yield loss worldwide, and it corresponds to more than 50\% of yield loss in high-yield cultivated plants (Wang et al. 2004). Drought is considered one of the significant abiotic stresses, and it alters the average growth balance in plants negatively. It also damages plants' growth and productivity by causing a series of morphological, physiological, biochemical, and molecular changes (Pandey et al. 2017). Researches on obtaining drought-resistant plant varieties are critical in challenging drought.

Morus nigra L. (black mulberry) is in Urticales order Moraceae family and Morus genus. Morus is widely cultivated, particularly in East, West, Southeast Asia, Southern Europe, the south of North America, the northwest of South America, and some parts of Africa (Datta 2002). Mulberry can be grown in temperate and subtropical climates due to its high ability to adapt to different climatic and soil conditions. Therefore, it has been reported that mulberry will have significant potential bio-energy plants in a rapidly changing global climate under drought conditions (Sekhar et al. 2017).

Mulberry in Turkey is cultivated as a closure and mixed garden or border plant. The fact that urbanization damages the genetic diversity of the mulberry made the protection of varieties critical (Vijayan et al. 2011). Narrowing of agricultural lands and the inverse effect of stress on environmental conditions are reasons for decreased productivity. Thus, it is very substantial to increase productivity in vegetative production, which is achieved by breeding or selecting resistant plants to stress conditions (Arici \& Eraslan 2012). Sugar, organic acids, minerals, anthocyanins, and vitamins included in black mulberry make it an essential source of nourishment. Most of the daily calcium, iron, B, and C vitamin requirements can be met by eating black mulberry (Hepsag et al. 2012; Wang et al. 2021). It has also been used in traditional herbal medicine for both animals and humans. It exhibited anti-inflammatory, antimicrobial, anti-diabetic, anti-obesity, and anticancer properties (Lim \& Choi 2019; 
Erden 2021; Mehta \& Kumar 2021). In this regard, it is essential to determine the drought resistance of $M$. nigra, which has medical and economic importance.

Avoidance and tolerance are two primary defence mechanisms that allow the plant to survive under drought stress (Zheng et al. 2017a). Drought tolerance is the ability to keep the plant tissue's physiological and metabolic activities at lower levels when the water potential within the plant decreases (Blum \& Ebercon 1981). Plants under drought stress have an effective defence system that uses enzymatic antioxidant systems consisting of antioxidants such as superoxide dismutase (SOD), catalase (CAT), peroxidase (POD), ascorbate peroxidase (APX), glutathione reductase (GR) and Glutathione-S-transferase (GST) as well as a non-enzymatic antioxidant system including some secondary metabolites such as ascorbic acid, GSH, flavonoids, and total phenols to mitigate the deleterious effects of reactive oxygen species (ROS) (Cheng et al. 2018).

Melatonin (MEL) has long been considered an important antioxidant or hormone in animals (Reiter 1991). Recently, it has been proven that endogenous MEL is widely found in bacteria, fungi, animals, and plants (Lin et al. 2019; Qiao et al. 2019). Also, MEL is recognized as a potential growth stimulator in plants (Arnao \& Hernández-Ruiz 2019; 2020). MEL acts as the primary regulator by increasing tolerance to biotic and abiotic stresses such as salinity, drought, extreme temperatures, high light intensity, herbicides, ultraviolet radiation (Zhang et al. 2012; Wang et al. 2017; Jahan et al. 2019; Ahammed et al. 2020a; Moustafa-Farag et al. 2020). A compound's qualification as a plant hormone It must be formed within the plant, transported from where it is formed to another location, and be able to manage or regulate various life events in the location where it is transported. It must be able to show these effects even at very low concentrations (Kaynak \& Ersoy 1997). MEL can dissolve both in water and lipids and easily reach all intracellular components (Posmyk \& Janas 2009). It can effectively protect the cell membrane, organelles, and nucleus from free radicals' devastating effect. Poeggeler et al. (2002) reported that MEL is also a more potent antioxidant than vitamins C, E, and K. According to our literature exploration on the effects of MEL on the antioxidant system, we could not find any study of applications to plants in the form of trees. However, there were many kinds of research conducted with herbaceous plants.

In this study, M. nigra cv. 'Eksi Kara', which has economic and medical importance, was reproduced in tissue culture, and groups were formed, in which MEL and drought stress (-1.5 MPa) was applied, in vitro. Also, pigment content, RWC, GSH, total phenol, proline content, and antioxidant enzyme activities (CAT, SOD, GST, GR, POD, and APX) were evaluated comparatively in both groups.

\section{Material and Methods}

\subsection{Plant growth in tissue culture}

The M. nigra cv. 'Eksi Kara' explants used in the research were obtained from the National Mulberry Gene Resources parcel located in in the Republic of Turkey, Ministry of Agriculture and Forestry, Malatya Apricot Research Institute. 'Eksi Kara' is the only $M$. nigra variety registered in the Seed Registration and Certification Center, and its fruits are economically and pharmacologically important. Explants were taken from nodal buds on one-year shoots in June, July, and August in 2017-2019. Explants were reproduced in MS medium (Murashige \& Skoog 1962, M0222 Duchefa) after surface sterilization. In the first phase of culture, $0.75 \mathrm{mg} \mathrm{L}^{-1}$ benzyl amino purine (BAP) was used, then $1 \mathrm{mg} . \mathrm{L}^{-1}$ BAP for shoot propagation, and $1.5 \mathrm{mg} . \mathrm{L}^{-1}$ indole butyric acid for rooting.

\subsection{Drought and melatonin application}

Plants were grown over a period of 5 months prior to application. Following applications were made to the plants rooted in vitro tissue culture: Control: Liquid (agar-free) MS medium was used. Control+MEL: The plants rooted under in vitro conditions were transferred to a liquid MS medium containing $20 \mu \mathrm{M}$ MEL. The MEL dose was chosen as a result of preliminary evaluations based on reference studies (Korkmaz et al. 2016; Han et al. 2017; Zheng et al. 2017b). PEG group: Plants were transferred to a liquid MS medium containing PEG 8000, a polymer that retains water, to provide the drought condition. To reach $-1.5 \mathrm{MPa}$ drought, 355 g.L.-1 PEG 8000 was added to the liquid MS medium according to the formula developed by Michel (1983).

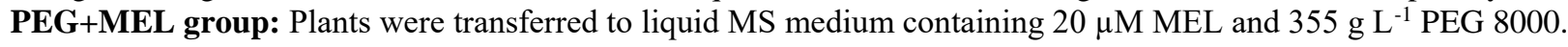

$$
\begin{gathered}
P E G=\frac{4-\sqrt{(5.16 \Psi T-560 \Psi+16)}}{(2.58 T-280)} \times 1000 \\
\Psi=-1.5 \mathrm{MPa} \mathrm{T}=25^{\circ} \mathrm{C}
\end{gathered}
$$

\subsection{Samples for analysis}

The leaves to be used in the analysis were taken on the $5^{\text {th }}, 10^{\text {th }}$, and $15^{\text {th }}$ days after the applications. Samples were frozen in liquid nitrogen and preserved at $-40{ }^{\circ} \mathrm{C}$ to be used for analysis. They were studied as soon as possible to eliminate the risk of loss of enzymatic activity. Fresh leaves were used without freezing to evaluate the relative water content. 


\subsection{Determination of relative water content}

Fresh weights $(\mathrm{FW})$ of the leaf samples were determined. Then, these leaves were kept in distilled water for 4 hours, and their turgor weights (TW) were determined. After drying for 48 hours in a $70{ }^{\circ} \mathrm{C}$ drying oven, the dry weights (DW) of samples were weighed. (Sanchez et al. 2004; Demiral \& Turkan 2005).

\subsection{Determination of total chlorophyll and carotenoid content}

The method of De Kok \& Graham (1980) was used for pigment content. In the first step, $1 \mathrm{~g}$ sample taken from the leaf was homogenized in $50 \mathrm{~mL}$ acetone $\left(100 \%\right.$ Merck) and kept at $+4{ }^{\circ} \mathrm{C}$ for 24 hours. Homogenates were then centrifuged, and their absorbance values were calculated according to Lichtenthaler \& Welburn (1983) with spectrophotometric reading (Biochrom Libra S22) at 662, 645, $470 \mathrm{~nm}$.

\subsection{Extraction for enzyme analysis}

To analyze enzyme, $0.5 \mathrm{~g}$ leaves were homogenized with $2.5 \mathrm{~mL} 0.1 \mathrm{M}, \mathrm{pH} 7.5$, Tris-HCl buffer, $2.5 \mathrm{~mL} 0.1 \mathrm{mM}$ EDTA and $0.5 \mathrm{~mL} 1 \%$ PVP. The homogenate was centrifuged at $+4{ }^{\circ} \mathrm{C}$ and $18.000 \mathrm{rpm}$ for 30 minutes. Then, the supernatant was stored at $-40{ }^{\circ} \mathrm{C}$ until analysis (Andrews et al. 2005). Enzyme values were calculated in terms of specific activity by dividing by total protein.

\subsection{CAT activity}

The method of Luck (1963) was used to determine CAT enzyme activity. CAT enzyme activity was defined as the absorbance change obtained in 1 minute by reading at $240 \mathrm{~nm}$ in the spectrophotometer (molar extinction coefficient for $\mathrm{H}_{2} \mathrm{O}_{2}$ is 0.0396 $\left.\mathrm{cm}^{2} \cdot \mu \mathrm{mol}^{-1}\right)$.

\subsection{SOD activity}

SOD enzyme activity determination was made using the method of McCord \& Fridovich (1969). The SOD activity was measured spectrophotometrically at $550 \mathrm{~nm}$.

\subsection{GST activity}

The method of Habig et al. (1974) used to assign GST enzyme activity. Enzyme activity was determined as $344 \mathrm{~nm}$ in the spectrophotometer (the extinction coefficient of CDNB is $9.6 \mathrm{mM}^{-1} \cdot \mathrm{cm}^{-1}$ ).

\subsection{GR activity}

Determination of GR activity was made according to Carlberg \& Mannervik (1985) method. Enzyme activity was measured in the spectrophotometer at $340 \mathrm{~nm}$ wavelength. NADPH was calculated with an extinction coefficient of $6.2 \mathrm{mM}^{-1} . \mathrm{cm}^{-1}$.

\subsection{GSH content}

Assignation of total glutathione content was made according to the method of Akerboom \& Sies (1981). One-minute absorbance change was determined at $412 \mathrm{~nm}$.

\subsection{POD activity}

The method of Peters et al. (1989) and MacAdam et al. (1992) was performed for POD activity determined with modification. The change in enzyme activity in the first minute was measured at the wavelength of $436 \mathrm{~nm}$ (Guaicol's extinction coefficient is $\left.26.6 \mathrm{mM}^{-1} \cdot \mathrm{cm}^{-1}\right)$.

\subsection{APX activity}

The methods of Nakano \& Asada (1981) and Cakmak (1994) were used for APX activity determination. Enzyme activity was determined at $290 \mathrm{~nm}$ in the spectrophotometer, and APX activity was calculated with an extinction coefficient of $2.8 \mathrm{mM}^{-1} . \mathrm{cm}^{-1}$.

\subsection{Determination of MDA content}

MDA analysis was made according to the method of Heath \& Packer (1968). The absorbance of the supernatant was measured at 532 and $600 \mathrm{~nm}$. The content of MDA was calculated with an extinction coefficient of $155 \mathrm{mM}^{-1} \cdot \mathrm{cm}^{-1}$. 


\subsection{Determination of total phenolic}

Slinkard \& Singleton's (1977) and Chandler \& Dodds' (1983) method used to determine the total phenolic determination. It was measured at $760 \mathrm{~nm}$ in the spectrophotometer, and a standard curve was prepared with the gallic acid solution.

\subsection{Determination of proline content}

Proline determination was made spectrophotometrically by the acid-ninhydrin method according to Bates et al. (1973). The absorbance was measured at a wavelength of $520 \mathrm{~nm}$. The same method was repeated using proline, and a standard graphic was created.

\subsection{Total protein content}

Total protein content was determined using the method of Bradford (1976). $50 \mu \mathrm{L}$ of homogenate prepared from leaves was added onto $1000 \mu \mathrm{L}$ Bradford reagent. It is measured in a spectrophotometer at a wavelength of $595 \mathrm{~nm}$.

\subsection{Statistical analysis}

SPSS (Statistical Program in Social Sciences) V.25 software was used to evaluate this study's data. The data's compliance with normal distribution was checked with the Shapiro - Wilk test, and the homogeneity of variances was controlled with the LEVENE test at the 5\% threshold. Duncan's multiple range test (Duncan 1955) was performed for paired comparisons of groups, and variance analysis (ANOVA) was made. Differences between the means were showed with different letters (P>0.05). Statistically same groups were showed with the same letters $(\mathrm{P}>0.05)$. Lower case letters show the comparison between averages in days (within groups), upper case letters show the comparison between groups. Each stage $\left(5^{\text {th }}, 10^{\text {th }}\right.$, and $15^{\text {th }}$ days) was compared within itself with Duncan's multiple range test.

\section{Results}

\subsection{Relative water content}

It was found that RWC decreased in the application of PEG to M. nigra leaves compared to the Control $(\mathrm{P}<0.05)$. The highest RWC was $64.11 \%$ in the Control+MEL group, while the lowest RWC was $21.11 \%$ in the PEG group. Moreover, there was a substantial decrease in RWC in different PEG group days $(\mathrm{P}<0.05)$ (Figure 1).

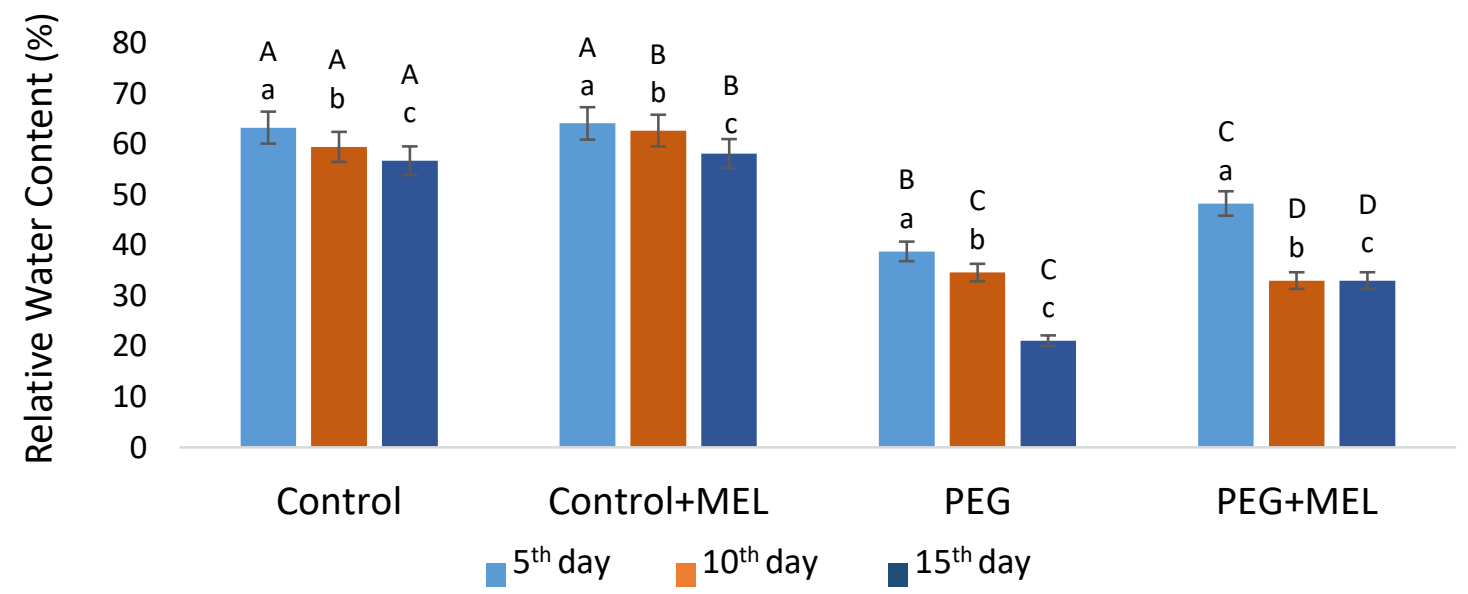

Figure 1- Relative water content changes in M. nigra leaves depending on groups and days

\subsection{Total chlorophyll and carotenoid content}

The total chlorophyll content was lower in all treatment groups than in the Control $(\mathrm{P}<0.05)$. The highest total chlorophyll content was $11.43 \mu \mathrm{g} . \mathrm{g}^{-1}$ in the control group, while the lowest was $4.54 \mu \mathrm{g} . \mathrm{g}^{-1}$ in the PEG group. Higher total chlorophyll content was observed in the PEG+MEL group compared to the PEG group. These differences were found to be statistically significant $(\mathrm{P}<0.05)$ (Figure 2). The carotenoid content was lower in all treatment groups than in the control group $(\mathrm{P}<0.05)$. The highest carotenoid content was observed as $2.57 \mu \mathrm{g}^{-\mathrm{g}^{-1}}$ in the Control+MEL group, while the lowest was $1.46 \mu \mathrm{g} \cdot \mathrm{g}^{-1}$ in PEG+MEL group. PEG+MEL group were determined lower than the PEG group in terms of carotenoid content $(\mathrm{P}<0.05)($ Figure 3$)$. 


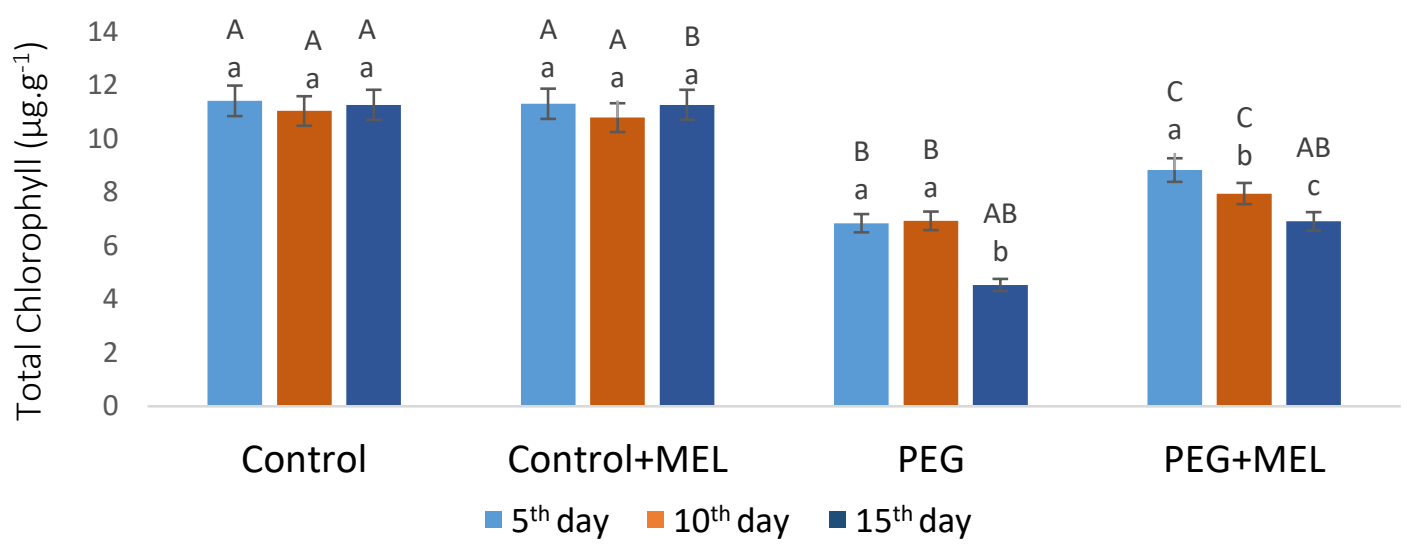

Figure 2- Variation of total chlorophyll content of M. nigra leaves depending on groups and days

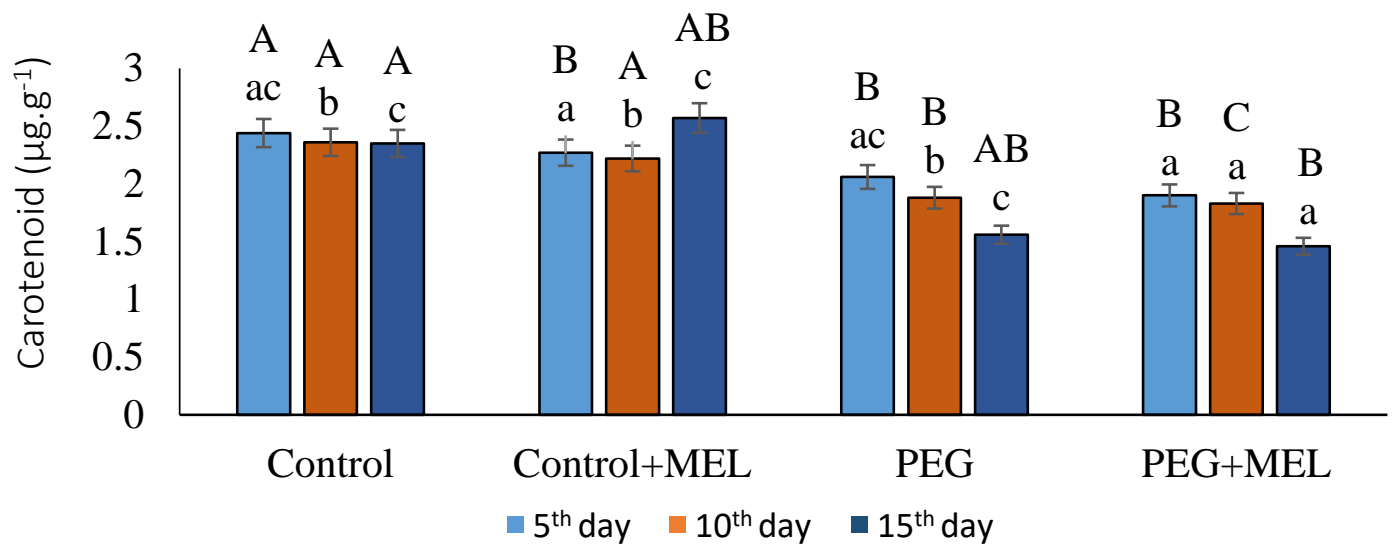

Figure 3- Variation of carotenoid content of M. nigra leaves depending on groups and days

\subsection{CAT activity}

CAT activity increased in all groups treated than the Control group $(\mathrm{P}<0.05)$. The highest enhancement in PEG+MEL group was found by $40 \%$ on the 10 th day and $57 \%$ on the $15^{\text {th }}$ day than the PEG group $(\mathrm{P}<0.05)$. On the other hand, CAT activity improved by $19 \%$ on the 5 th day and $39 \%$ on the $10^{\text {th }}$ day in Control+MEL group compared to the Control group (P<0.05) (Figure 4$)$.

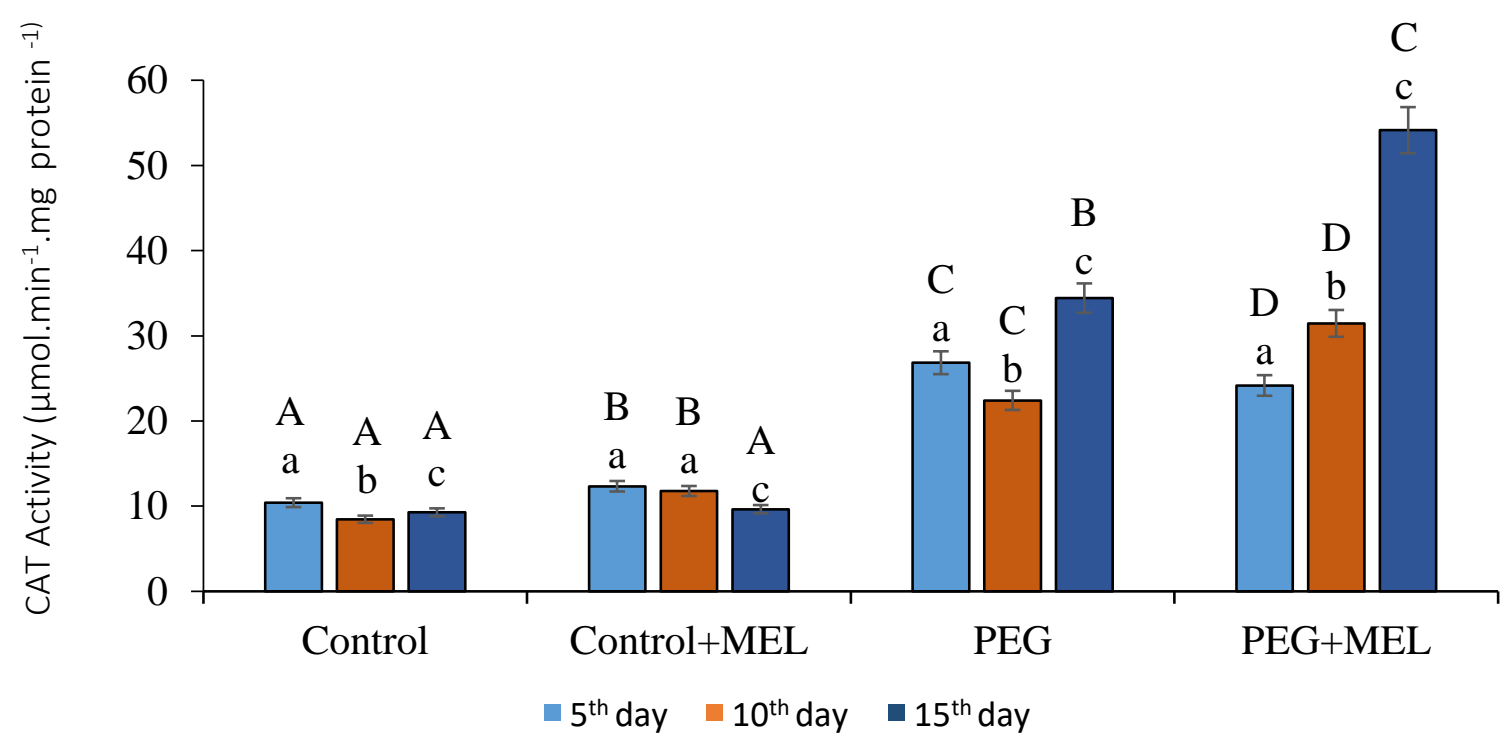

Figure 4- Variation of CAT activity in M. nigra leaves depending on groups and days 


\subsection{SOD activity}

We determined improvement in SOD activity in all treatments, excluding the Control group $(\mathrm{P}<0.05)$. The highest SOD activity was found in PEG+MEL group as $97.06 \mu \mathrm{mol}_{\mathrm{min}}{ }^{-1} \mathrm{mg}$ protein ${ }^{-1}$. We also observed that SOD activity increased $100 \%$ on the 10 th day and $92 \%$ on the $15^{\text {th }}$ day in the PEG+MEL group compared to the PEG group $(\mathrm{P}<0.05)$. Also, MEL supplementation to the Control group enhanced SOD activity by $52 \%$ on the $10^{\text {th }}$ day and $384 \%$ on the $15^{\text {th }}$ day $(\mathrm{P}<0.05)$ (Figure 5$)$.

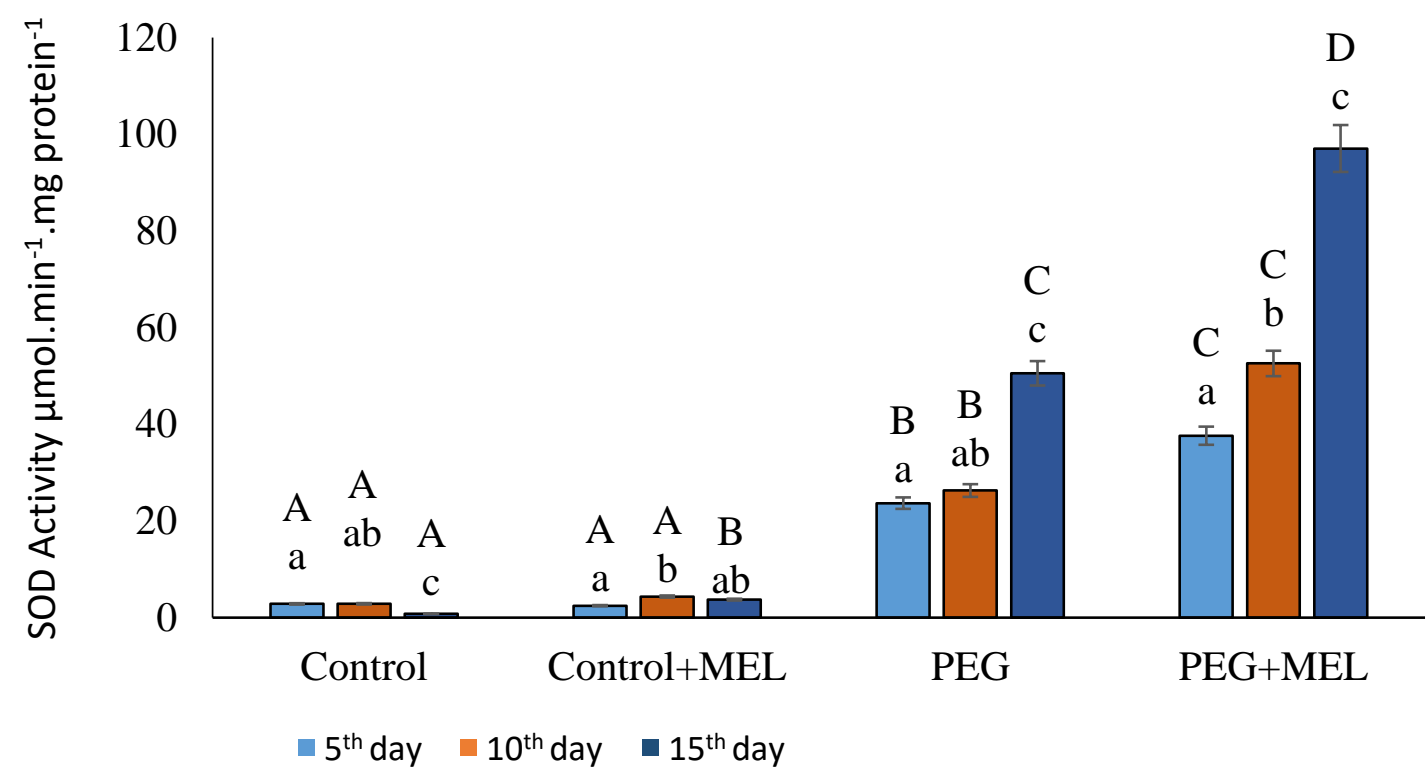

Figure 5- Variation of SOD activity in M. nigra leaves depending on groups and days

\subsection{GST activity}

It was determined that the GST activity increased in all the treatment groups compared to the Control $(\mathrm{P}<0.05)$. The highest GST activity was $66.57 \mu \mathrm{mol} \cdot \mathrm{min}^{-1} \cdot \mathrm{mg}$ protein ${ }^{-1}$ in PEG+MEL group, and increasing by $125 \%$ was found compared to the $15^{\text {th }}$ day of the PEG group (Figure 6).

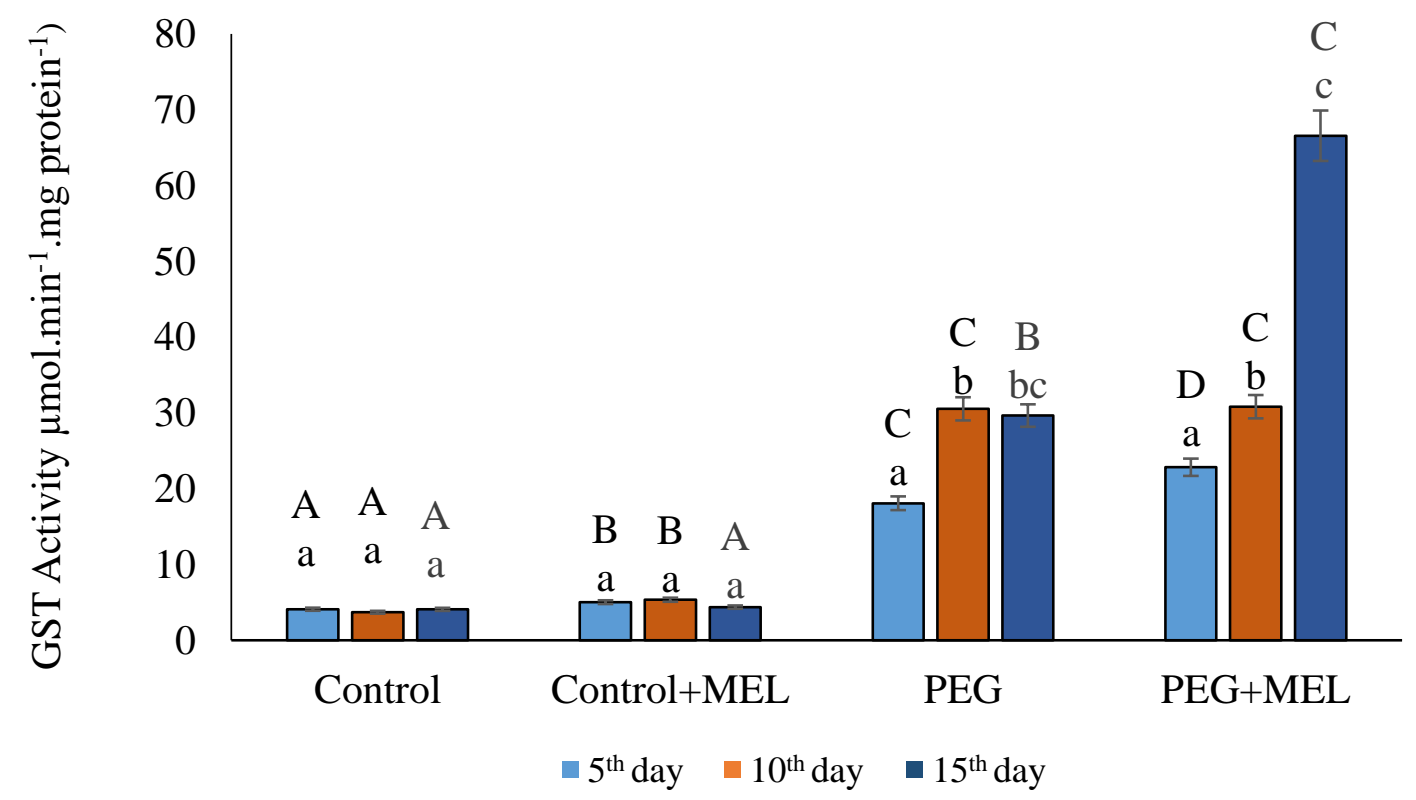

Figure 6- Variation of GST activity in M. nigra leaves depending on groups and days 


\subsection{GR activity}

GR activity increased in all treatment groups compared to the Control $(\mathrm{P}<0.05)$. The highest GR activity was found in PEG+MEL group as $124.48 \mu \mathrm{mol} . \mathrm{min}^{-1}$.mg protein ${ }^{-1}$. Compared to the PEG group, GR activity in PEG+MEL group decreased $12 \%$ on the 5 th day, while increased $28 \%$ on the $10^{\text {th }}$ day and $55 \%$ on the $15^{\text {th }}$ day $(\mathrm{P}<0.05)$ (Figure 7$)$.

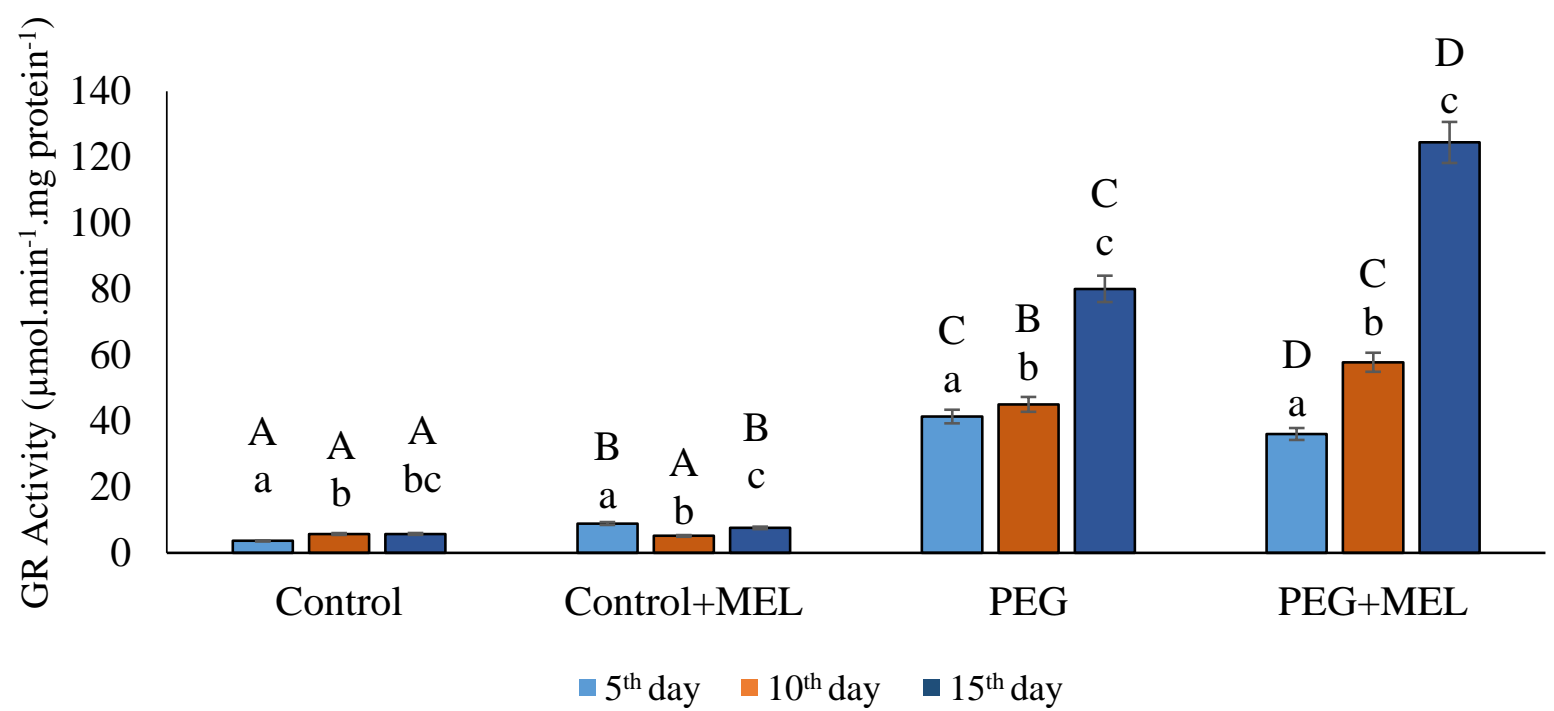

Figure 7- Variation of GR activity in M. nigra leaves depending on groups and days

\subsection{GSH content}

It was seen that treatment groups, excluding Control, positively impacted GSH content $(\mathrm{P}<0.05)$. The highest GSH content detected in the PEG+MEL group was $2.34 \mu \mathrm{mol} . \mathrm{min}^{-1} . \mathrm{mg}$ protein ${ }^{-1}$. It was found that the PEG+MEL group improved, compared to the PEG group, $38 \%$ on the $10^{\text {th }}$ day and $93 \%$ on the $15^{\text {th }}$ day $(\mathrm{P}<0.05)$ (Figure 8$)$.

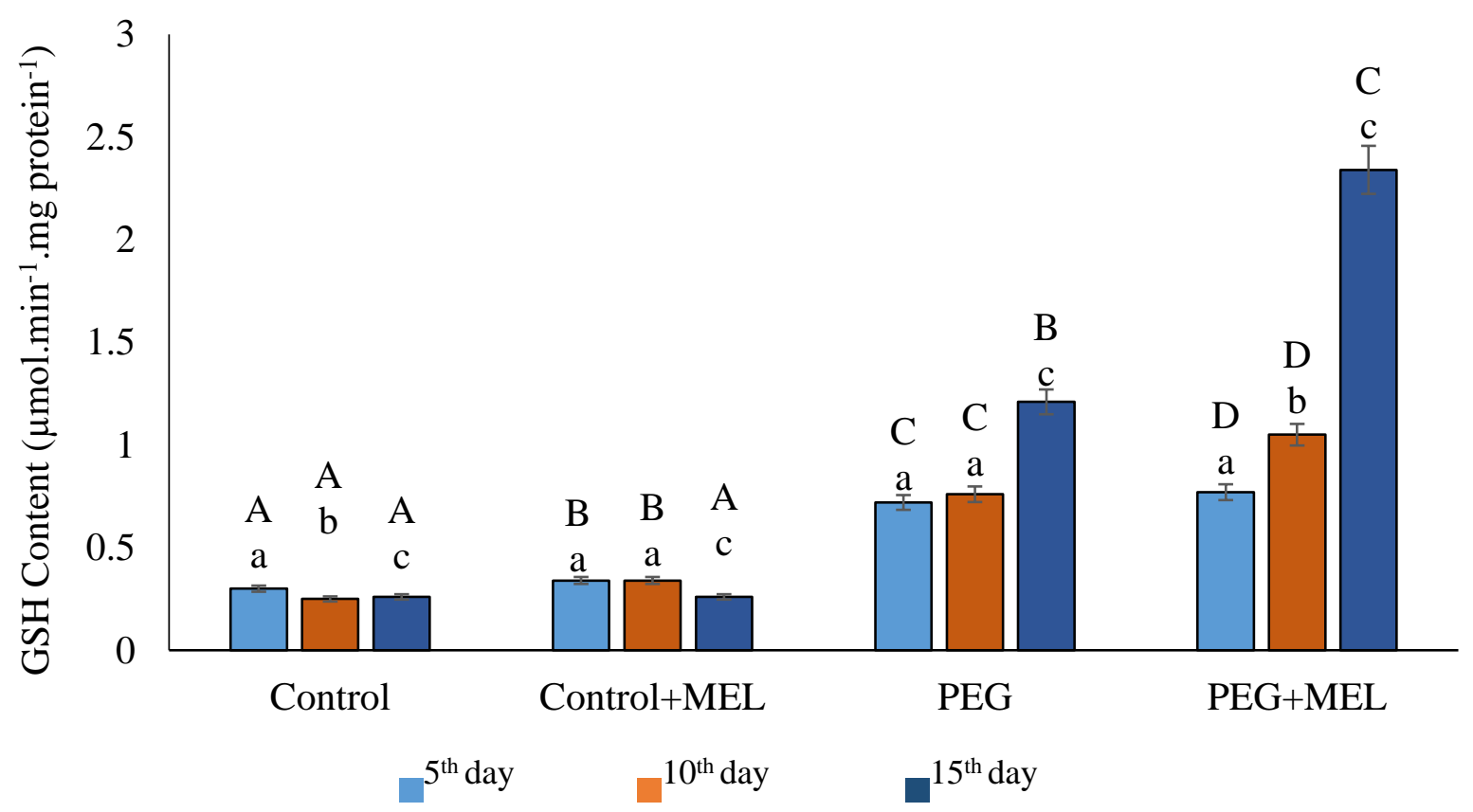

Figure 8- Variation of GSH content in M. nigra leaves depending on groups and days 


\subsection{POD activity}

Our findings showed that PEG application increased POD activity in $M$. nigra leaves compared Control group on all days $(\mathrm{P}<0.05)$. The highest POD activity was observed in the PEG+MEL group with $3.92 \mu \mathrm{mol} \mathrm{min}^{-1}$. $\mathrm{mg} \mathrm{protein}^{-1}$. The PEG+MEL group enhanced POD activity by $48 \%$ on the $5^{\text {th }}$ and $10^{\text {th }}$ days and by $92 \%$ on the $15^{\text {th }}$ day when compared to the PEG group $(\mathrm{P}<0.05)$ (Figure 9).

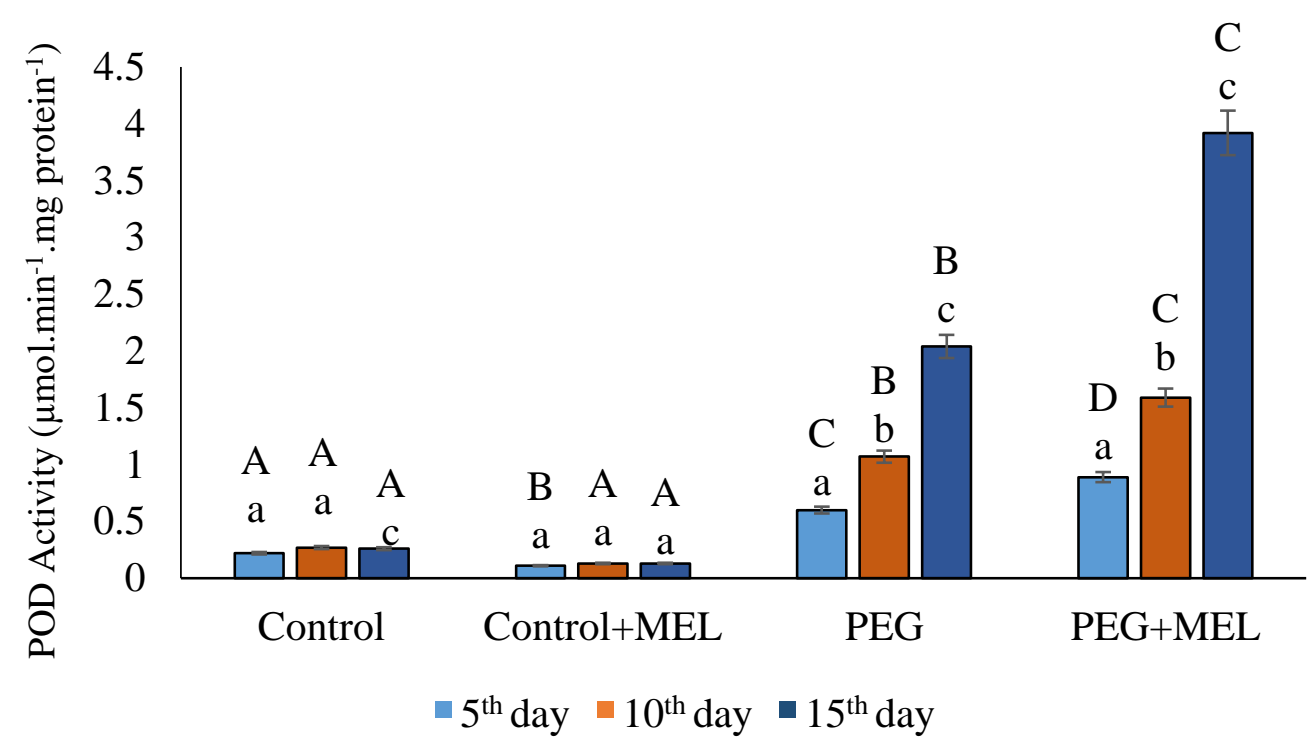

Figure 9- Variation of POD activity in M. nigra leaves depending on groups and days

\subsection{APX activity}

It was seen that APX activity in $M$. nigra leaves increased along with PEG treatment compared to the Control group on all days $(\mathrm{P}<0.05)$. The highest APX activity was found in the PEG+MEL group with $317.59 \mu \mathrm{mol}^{\mathrm{min}} \mathrm{m}^{-1}$. $\mathrm{mg} \mathrm{protein}^{-1}$. In this context, it was observed that improvement was $84 \%$ on the $10^{\text {th }}$ and $15^{\text {th }}$ days in $\mathrm{PEG}+\mathrm{MEL}$ group compared to the $\mathrm{PEG}$ group $(\mathrm{P}<0.05)$ (Figure 10).

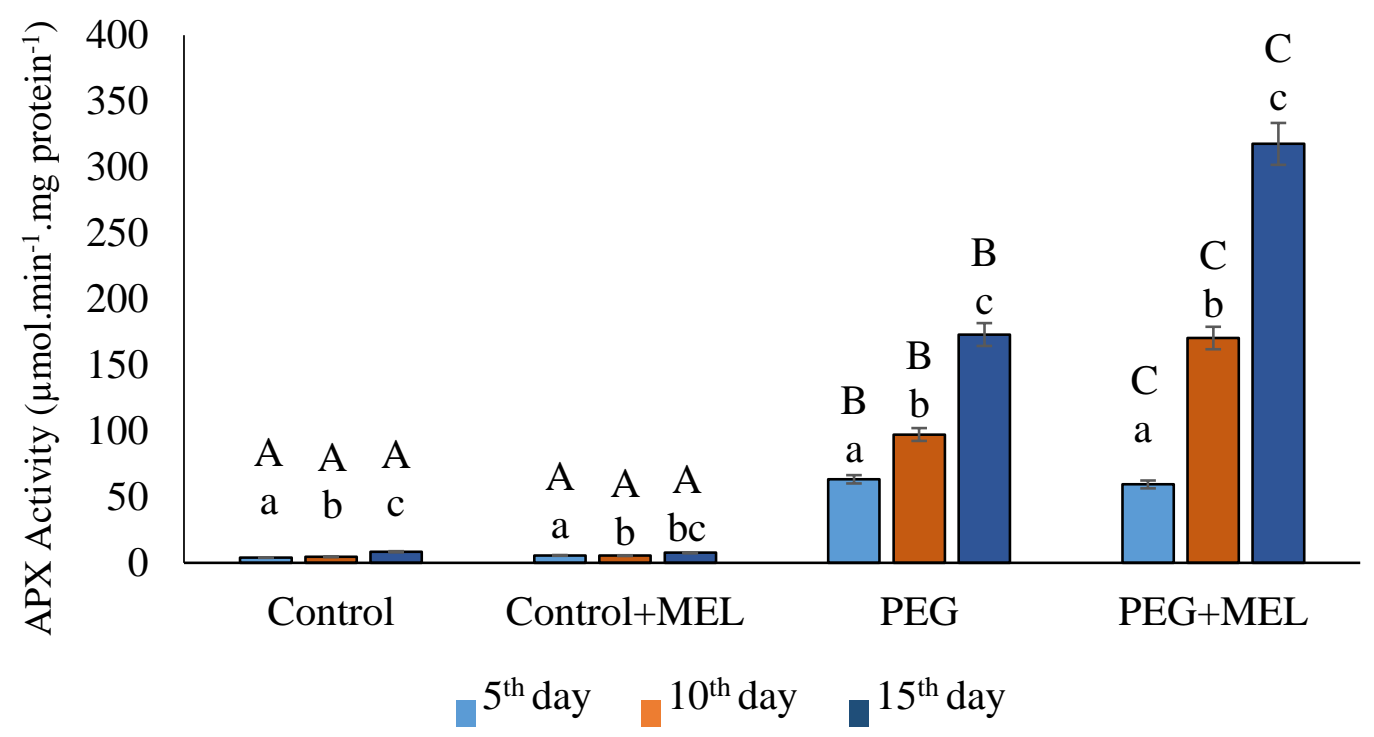

Figure 10- Variation of APX activity in M. nigra leaves depending on groups and days 


\subsection{MDA content}

When compared with the Control group, it was determined that the MDA content of $M$. nigra leaves increased on all days with PEG application $(\mathrm{P}<0.05)$. On the other hand, the highest MDA content was examined as $27.75 \mu \mathrm{mol}$ MDA.g ${ }^{-1} \mathrm{FW}$ in the PEG group. (P>0.05) (Figure 11).

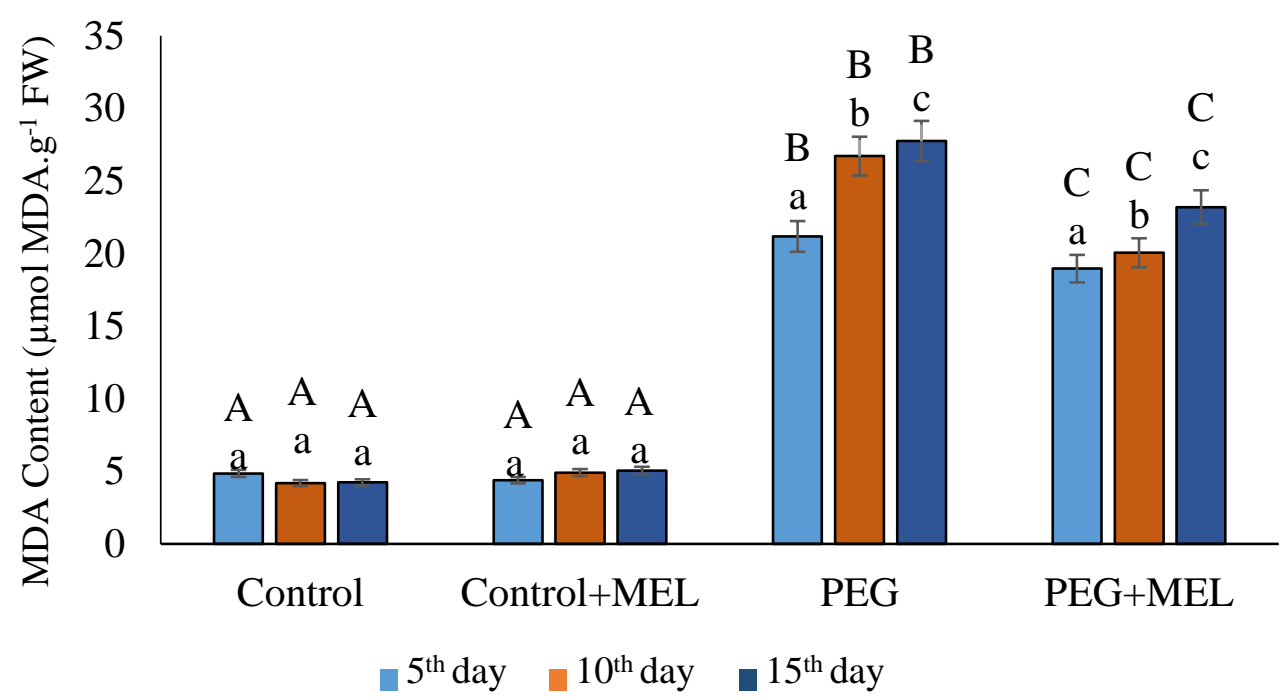

Figure 11- Variation of MDA content in M. nigra leaves depending on groups and days

\subsection{Total phenolic content}

The highest total phenolic content was found as $13.5 \mu \mathrm{g} . \mathrm{g}^{-1} \mathrm{FW}$ in the PEG+MEL group. On the other hand, it was observed that PEG+MEL group enhanced total phenolic content by $17 \%$ on the $5^{\text {th }}$ day, $12 \%$ on the $10^{\text {th }}$ day, and $53 \%$ on the $15^{\text {th }}$ day compared with the PEG group $(\mathrm{P}<0.05)$. Analysis results indicate that there was no difference between the Control+MEL and Control group in terms of total phenolic content $(\mathrm{P}>0.05)$ (Figure 12).

\subsection{Proline content}

Our findings indicate that proline content was higher in all treatment groups than in the Control group $(\mathrm{P}<0.05)$. The highest proline content was found as $115.11 \mu \mathrm{g} . \mathrm{g}^{-1} \mathrm{FW}$ in PEG+MEL group. Exogenous MEL application to the PEG group improved proline content by $32 \%$ on the $5^{\text {th }}$ day, $20 \%$ on the $10^{\text {th }}$ day, and $17 \%$ on the $15^{\text {th }}$ day $(\mathrm{P}<0.05)$ (Figure 13).

\section{Discussion}

Drought has become the most critical problem limiting agricultural production. Moreover, it ranks first according to evaluating the adverse effects of natural disasters in the world (Marchin et al. 2020). In this context, to find solutions to yield losses caused by drought, understanding plants' mechanisms that could adapt to deficient water conditions is crucial. Studies on different plant species have shown that PEG can successfully provide drought stress conditions to plants (Zhu et al. 2005; Rouhi et al. 2006; Caruso et al. 2008; Chen et al. 2010; Ipek 2015). Also, PEG has a substantial impact on plants' water uptake by affecting its environment's osmotic potential. Hence, the intensity of use of PEG causes different levels of drought stress.

The soil's water potential is, on average, -1.5 MPa at the permanent wilting point (Kocacaliskan 2008). Leaf water content reflects the ability of the plant leaves to maintain water balance. On the other hand, RWC in plant leaves is reduced as soil moisture decreases (Marshall et al. 2000; Chen et al. 2012). It has been reported by Korkmaz et al. (2016) that chilling injury stress caused a diminishment in RWC in the leaves of pepper seedlings while MEL treatment enhanced it. In this study, although RWC was observed to be lower in the PEG group compared to the Control group, PEG+MEL composition improved RWC. Also, MEL was potent in protecting RWC and water potential in M. nigra exposed to drought (Figure 1).

According to Santos (2004), decreasing chlorophyll biosynthesis or increase in chlorophyll fragmentation is the cause of degradation in chlorophyll content in plants. On the other hand, Fracheboud et al. (2004) stated that drought stress might reduce chlorophyll and carotenoid content. They also reported that it is closely related to the carbon exchange ratio. Drought prevents photosynthesis by causing inconsistency in the light-harvesting complex, which triggers oxidative stress (Smirnoff 1993). Our 
findings showed that PEG treatment in M. nigra negatively affected the pigment system. The enhancement of the total chlorophyll content in the PEG+MEL group indicates that MEL positively affects the pigment system (Figure 2).

Carotenoids are a photoprotective agent used to mitigate the deleterious effects of light and oxygen. They protect all photosynthetic organisms against light damage by transforming the light into heat or detoxifying ROTs, which leads to a reduction in lipid peroxidation (Collins 2001). Sharma et al. (2020) determined that MEL's application to Carya cathayensis (Chinese hickory) plants under drought stress conditions regulates metabolic pathways such as phenylpropanoid, chlorophyll, and carotenoid biosynthesis, and carbon fixation. Our findings regarding carotenoid content indicate that the decrease in PEG and PEG+MEL groups' carotenoid content may be due to the consumption of carotenoids in the plant during challenges with drought stress (Figure 3).

Free radical-induced peroxidation of lipid membranes is both the reflection and measurement of stress-induced damage at the cellular level (Jain et al. 2001). MDA is the end-product of membrane lipid peroxidation, and its accumulation demonstrates that plant cells have high levels of lipid peroxides (Zhao \& Tan 2005; Upadhyaya et al. 2007; Liu et al. 2014; Ju et al. 2018). On the other hand, plant resistance can be assessed by measuring the MDA content (Gao et al. 2020). According to our findings, the MDA content was the highest in the PEG group's drought stress compared to the Control group. It was also observed that MEL+PEG group, interestingly, had lower MDA content compared to the PEG group. In this context, it is thought that MEL prevented membrane lipid peroxidation, while drought stress increased MDA content as well as the simultaneous application of MEL and PEG decreased MDA content (Figure 11). According to some studies, the MDA content decreased in groups that applied melatonin under stress ( $\mathrm{Li}$ et al. 2019; Imran et al. 2021). The obtained findings indicate that MEL might alleviate abiotic stress-triggered ROS accumulation and cell membrane damage.

CAT is one of the antioxidant enzymes that affect cell life as it contributes to coping with ROS, which forms in oxidative stress (Volkert et al. 1994). In the study of Huihui et al. (2020), it was reported that SOD and CAT activity was increased in leaves of mulberry (M. alba L.) seedlings exposed to $\mathrm{NaCl}$ stress, and $\mathrm{O}_{2}$ accumulation was not observed. Liu et al. (2015) reported that exogenous MEL application $(0.1 \mathrm{mM})$ to the roots of tomato (Lycopersicum esculentum) under drought stress conditions promoted CAT, SOD, POD enzyme activities, and AsA levels. It has been stated that this status is related to the alleviation of damage in the membranes and thus the enhancement in drought tolerance. We observed that our findings are coherent with this statement (Figures 4, 5, 9).

It has been reported that SOD plays a role in the antioxidant defence mechanism of plants during oxidative stress and increases the activity of this enzyme as a reaction to stress (Jacoby et al. 2010). Plant GSTs detoxify ROSs, which form as consequences of various stresses, and can reduce peroxides along with GSH (Gill \& Tuteja 2010). Kaya \& Doğanlar (2019) reported that proline, GSH, and MDA contents and APX, GST, and GR activities increased in peppers (Capsicum annuum) exposed to pendimethalin and drought stress. They also found that exogenous MEL application reduced the plants' MDA content compared to control plants, while the proline content, GSH, and antioxidant enzymes (APX, GST, and GR) activities increased. Oxidized glutathione and NADPH transform GSH again with the reaction catalyzed by GR reductase (GR), and GR is the only enzyme that catalyzes this recovery (Karuppanapandian et al. 2011; Guller et al. 2020). On the other hand, increasing GR activity in plants promotes GSH accumulation. Thus, resistance and tolerance can be formed in plants against oxidative stresses (Shereefa \& Kumaraswamy 2016). GR is the only enzyme that catalyzes the recovery of reduced glutathione from oxidized glutathione using NADPH as a reducing agent. In the research conducted by Xia et al. (2020), it is reported that exogenous MEL application to seedlings grown under drought stress led to the enhancement of ascorbic acid-glutathione (AsA-GSH) cycle, carotenoid biosynthesis, and antioxidant enzymes activities. It has been stated that the increase in POD activity under drought stress conditions is associated with the drought tolerance of the plant and that high POD activity will strengthen drought stress tolerance in the plant (Sairam \& Saxena 2000). In another study, Campos et al. (2019) reported that MEL application (300 $\mu \mathrm{M})$ increased the enzymatic and non-enzymatic antioxidants activity and reduced lipid peroxidation in coffee plants under water stress. Our findings indicate that SOD, GST, GR, POD, and APX enzyme activities and GSH content were increased in the PEG group compared to the Control group. Moreover, these parameters raised more in PEG+MEL group (Figures 5-10). We observed that MEL enhanced these enzymes, which are prominent in defence, and it demonstrates that MEL has a positive effect on the antioxidant system. These findings are in accordance with the literature.

Flavonoids and phenolic acids function as scavengers of free radicals and play a role in chelating ROS-producing metals by the Fenton reaction (Zhang et al. 2016). Gao et al. (2020), who experimented on two ornamental plants (Adonis amurensis and A. pseudoamurensis), reported that drought stress conditions improved flavonoid and total phenol content remarkably. Researchers also stated that plants mitigated damage caused by drought stress through soluble sugar and proline accumulation. Our findings indicate that drought stress increased the total phenolic content in M. nigra by 53\% in PEG+MEL treatment than in the PEG group (Figure 12). Literature results suggest that exogenous MEL application in drought stress conditions contributes to plants' defence mechanism in stress tolerance by enhancing the phenolic content. 


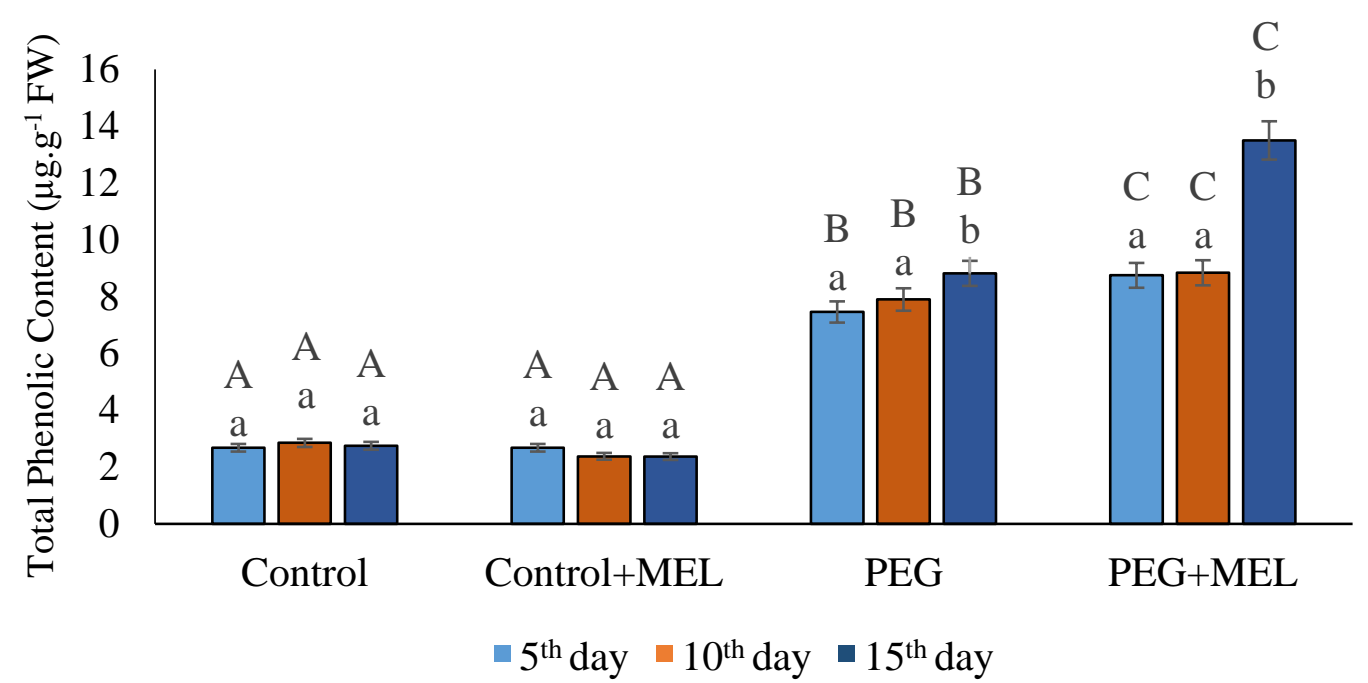

Figure 12- Variation of total phenolic content in $M$. nigra leaves depending on groups and days

Proline accumulation in plants preserves the moisture in the tissue, assists the absorption of water from the environment, and supports the cells to maintain their normal physiological and biochemical activities. Many studies have confirmed this finding in different plants under drought stress conditions (Karimi et al. 2012; Rostami \& Rahami 2013; Bolat et al. 2014; Ipek 2015). Besides, many researchers reported soluble sugar and protein increment also seen under drought stress conditions as a protective mechanism of plants (Sarker \& Oba 2018). Relative to the results of the study conducted by Ding et al. (2017), it was observed that exogenous MEL application to the leaves of tomato seedlings increased antioxidant enzyme activity, sugar, and proline content. Our findings demonstrated a similar trend in the M. nigra plant, and proline was higher, especially in the MEL group (Figure 13).

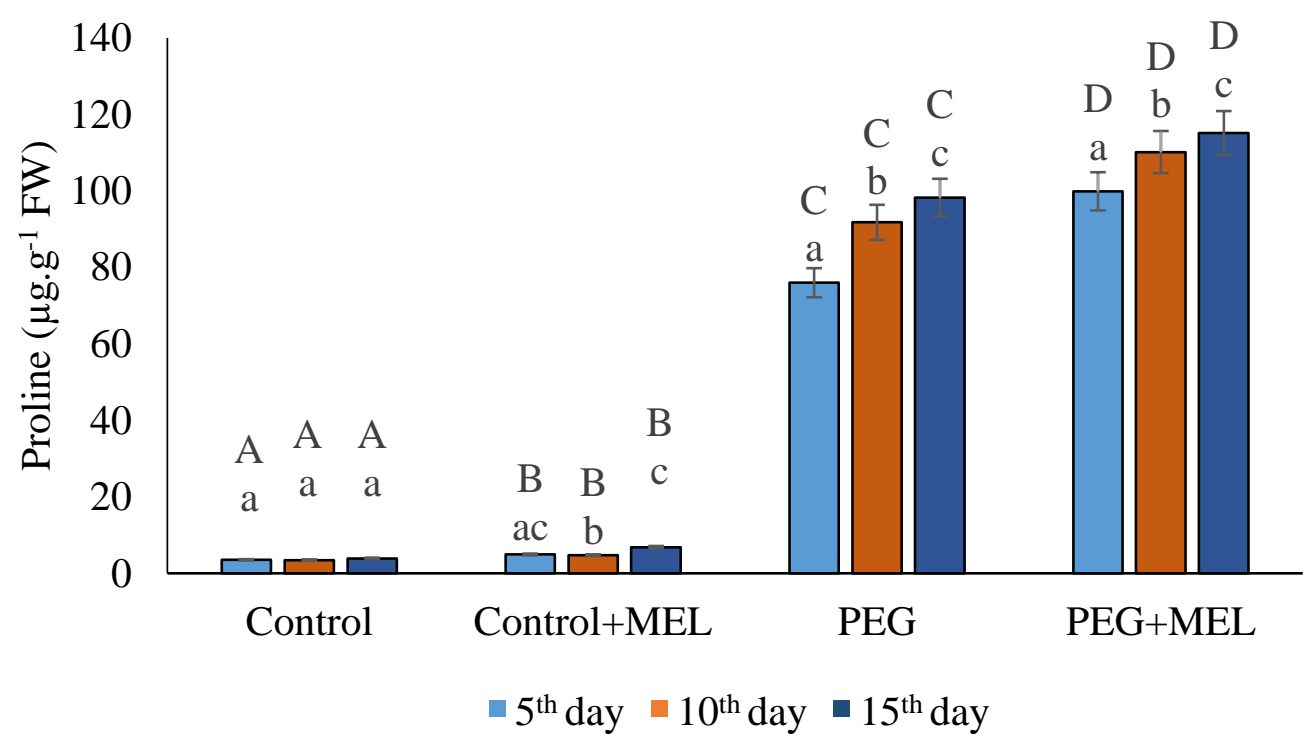

Figure 13- Variation of proline content in M. nigra leaves depending on groups and days

\section{Conclusions}

This study determined that MEL mitigates drought stress damage in M. nigra plants and could use as a protector. Moreover, our findings have shown that MEL positively impacts the pigment system, RWC, MDA content, non-enzymatic (GSH, proline, carotenoid), and enzymatic antioxidants (SOD, CAT, GST, GR, POD, APX). Hence, this study suggests significant findings to in vitro and in vivo research in the future. 


\section{Acknowledgements}

This research is a part of the doctoral thesis of Duygu ÖZELÇİ. We want to thank Inonu University Scientific Research Project Unit (Project No FDK-2017-682) for supporting the research, and Apricot Research Institute for their contribution in providing laboratory facilities and samples.

\section{References}

Ahammed G J, Wang Y, Mao Q, Wu M, Yan Y, Ren J, Wang X, Liu A \& Chen S (2020). Dopamine alleviates bisphenol A-induced phytotoxicity by enhancing antioxidant and detoxification potential in cucumber. Environmental Pollution 259: 113957. https://doi.org/10.1016/j.envpol.2020.113957

Akerboom T P \& Sies H (1981). Assay of glutathione, glutathione disulfide, and glutathione mixed disulfides in biological samples. In Methods in enzymology 77: 373-382 Academic Press. https://doi.org/10.1016/s0076-6879(81)77050-2

Andrews C J, Cummins I, Skipsey M, Grundy N M, Jepson I, Townson J \& Edwards R (2005). Purification and characterisation of a family of glutathione transferases with roles in herbicide detoxification in soybean (Glycine max L.); selective enhancement by herbicides and herbicide safeners. Pesticide Biochemistry and Physiology 82(3): 205-219. https://doi.org/10.1016/j.pestbp.2004.11.009

Arici E S \& Eraslan F (2012). The effect of salt stress on colt (Prunus avium X Prunus psudocerasus) cherry rootstock cultured in vitro conditions. Journal of Süleyman Demirel University Faculty of Agriculture 7(2):41-48 (In Turkish).

Arnao M B \& Hernández-Ruiz J (2019). Melatonin: a new plant hormone and/or a plant master regulator? Trends in Plant Science 24(1): 3848. https://doi.org/10.1016/j.tplants.2018.10.010

Arnao M B \& Hernández-Ruiz J (2020). Is phytomelatonin a new plant hormone? Agronomy 10(1): 95. https://doi.org/10.3390/agronomy10010095

Bates L S, Waldren, R P \& Teare I D (1973). Rapid determination of free proline for water-stress studies. Plant and Soil 39(1): 205-207. https://doi.org/10.1007/BF00018060

Blum A \& Ebercon A (1981). Cell membrane siability as a measure of drought and heat tolerance in wheat. Crop Sci 21: 43-47. https://doi.org/10.2135/cropsci1981.0011183X002100010013x

Bolat I, Dikilitas M, Ercisli S, Ikinci A \& Tonkaz T (2014). The effect of water stress on some morphological, physiological, and biochemical characteristics and bud success on apple and quince rootstocks. The Scientific World Journal. https://doi.org/10.1155/2014/769732

Bradford M M (1976). A rapid and sensitive method for the quantitation of microgram quantities of protein utilizing the principle of proteindye binding. Analytical Biochemistry 72(1-2): 248-254. https://doi.org/10.1006/abio.1976.9999

Cakmak I (1994). Activity of ascorbate-dependent $\mathrm{H}_{2} \mathrm{O}_{2}$-scavenging enzymes and leaf chlorosis are enhanced in magnesium-and potassiumdeficient leaves, but not in phosphorus-deficient leaves. Journal of Experimental Botany 45(9): 1259-1266. https://doi.org/10.1093/jxb/45.9.1259

Campos C N, ÁvilaRG de Souza K R D, Azevedo L M \& Alves J D (2019). Melatonin reduces oxidative stress and promotes drought tolerance in young Coffea arabica L. plants. Agricultural Water Management 211: 37-47. https://doi.org/10.1016/j.agwat.2018.09.025

Carlberg I \& Mannervik B (1985) Glutathione reductase. In Methods in Enzymology 113: 484-490. Academic press. https://doi.org/10.1016/s0076-6879(85)13062-4

Caruso A, Chefdor F, Carpin S, Depierreux C, Delmotte F M, Kahlem G \& Morabito D (2008). Physiological characterization and identification of genes differentially expressed in response to drought induced by PEG 6000 in Populus canadensis leaves. Journal of Plant Physiology 165(9): 932-941. https://doi.org/ 10.1016/j.jplph.2007.04.006

Chandler S F \& Dodds J H (1983). The effect of phosphate, nitrogen and sucrose on the production of phenolics and solasodine in callus cultures of Solanum laciniatum. Plant Cell Reports 2(4): 105-108. https://doi.org/10.1007/BF00270105

Chen J, Wu W, Zheng Y, Hou K, Xu Y \& Zai J (2010). Drought resistance of Angelica dahurica during seedling stage under polyethylene glycol (PEG-6000)-simulated drought stress. Zhongguo Zhong yao za zhi= Zhongguo Zhongyao Zazhi= China Journal of Chinese Materia Medica 35(2): 149-153. https://doi.org/10.4268/cjcmm20100205

Chen Y, Chen F, Liu L \& Zhu S (2012). Physiological responses of Leucaena leucocephala seedlings to drought stress. Procedia Engineering 28: 110-116. https://doi.org/10.1016/j.proeng.2012.01.691

Cheng L, Han M, Yang L M, Li Y, Sun Z \& Zhang T (2018). Changes in the physiological characteristics and baicalin biosynthesis metabolism of Scutellaria baicalensis Georgi under drought stress. Industrial Crops and Products 122: 473-482. https://doi.org/10.1016/j.indcrop.2018.06.030

Collins A R (2001). Carotenoids and genomic stability. Mutation Research/Fundamental and Molecular Mechanisms of Mutagenesis, 475(12): 21-28. https://doi.org/10.1016/s0027-5107(01)00071-9

Datta R K (2002). Mulberry cultivation and utilization in India. Mulberry for animal production. FAO Animal Production and Health Paper 147: 45-62

De Kok L J \& Graham M (1980). Levels of pigments, soluble proteins, amino acids and sulhydryl compounds in foliar tissue of Arabidopsis thaliana during dark-induced and natural senescence. Plant Physiology and Biochemistry (Paris) 27(2): 133-142.

Demiral T \& Turkan I (2005). Comparative lipid peroxidation, antioxidant defense systems and proline content in roots of two rice cultivars differing in salt tolerance. Environmental and Experimental Botany 53(3): 247-257. https://doi.org/ 10.1016/j.envexpbot.2004.03.017

Ding F, Liu B \& Zhang S (2017). Exogenous melatonin ameliorates cold-induced damage in tomato plants. Scientia Horticulturae 219: 264271. https://doi.org/ 10.1016/j.scienta.2017.03.029

Duncan D B (1955). Multiple range and multiple $F$ tests biometrics. International Biometric Society 11(1): 1-42. https://doi.org/10.2307/3001478

Erden Y (2021). Sour black mulberry (Morus nigra L.) causes cell death by decreasing mutant p53 expression in HT-29 human colon cancer cells. Food Bioscience 42: 101113. https://doi.org/10.1016/j.fbio.2021.101113

Fracheboud Y, Jompuk C, Ribaut J M, Stamp J \& Leipner P (2004). Genetic analysis of cold-tolerance of photosynthesis in maize. Plant Molecular Biology 56(2): 241-253. https://doi.org/10.1007/s11103-004-3353-6

Gao S, Wang Y, Yu S, Huang Y, Liu H, Chen W \& He X (2020). Effects of drought stress on growth, physiology and secondary metabolites of two Adonis species in Northeast China. Scientia Horticulturae 259: 108795. https://doi.org/ 10.1016/j.scienta.2019.108795 
Gill S S \&Tuteja N (2010). Reactive oxygen species and antioxidant machinery in abiotic stress tolerance in crop plants. Plant Physiology and Biochemistry 48(12): 909-930. https://doi.org/10.1016/j.plaphy.2010.08.016

Guller P, Karaman M, Guller U, Aksoy M \& Kufrevioglu O I (2020). A study on the effects of inhibition mechanism of curcumin, quercetin, and resveratrol on human glutathione reductase through in vitro and in silico approaches. Journal of Biomolecular Structure and Dynamics 1-10. https://doi.org/10.1080/07391102.2020.1738962

Habig W H, Pabst M J \& Jakoby W B (1974). The first enzymatic step in mercapturic acid formation Glutathione S-Transferases. J. Biol. Chem 249: 7130-7139. https://doi.org/10.1016/S0021-9258(19)42083-8

Han Q H, Huang B, Ding C B, Zhang Z W, Chen Y E, Hu C, Zhou L, Huang Y, Liao J, Yuan S \& Yuan M (2017). Effects of melatonin on anti-oxidative systems and photosystem II in cold-stressed rice seedlings. Frontiers in Plant Science 8: 785. https://doi.org/10.3389/fpls.2017.00785

Heath R L \& Packer L (1968). Photoperoxidation in isolated chloroplasts: I. Kinetics and stoichiometry of fatty acid peroxidation. Archives of Biochemistry and Biophysics 125(1): 189-198. https://doi.org/10.1016/0003-9861(68)90654-1

Hepsag F, Hayoglu I \& Hepsag B (2012). Anthocyanin content of black mulberry fruit and the possibilities of using anthocyanins as colorants in the food industry. Electronic Journal of Food Technologies 7(1): 9-19 (In Turkish).

Huihui Z, Xin L, Yupeng G, Mabo L, Yue W, Meijun A, Yuehui Z, Guanjun L, Nan X \& Guangyu S (2020). Physiological and proteomic responses of reactive oxygen species metabolism and antioxidant machinery in mulberry (Morus alba $\mathrm{L}$.) seedling leaves to $\mathrm{NaCl}$ and NaHCO3 stress. Ecotoxicology and Environmental Safety 193: 110259. https://doi.org/10.1016/j.ecoenv.2020.110259

Imran M, Latif Khan A, Shahzad R, Aaqil Khan M, Bilal S, Khan A, Kang S M \& Lee I J (2021). Exogenous melatonin induces drought stress tolerance by promoting plant growth and antioxidant defence system of soybean plants. AoB Plants 13(4): plab026. https://doi.org/10.1093/aobpla/plab026

Ipek M (2015). Determination of the responses of Garnem and Myrobolan 29C rootstocks to drought stress in vitro conditions. PhD Thesis, Selcuk University, Institute of Science and Technology, Konya Publication ID 409829 (In Turkish).

Jacoby R P, Millar A H \& Taylor N L (2010). Wheat mitochondrial proteomes provide new links between antioxidant defense and plant salinity tolerance. Journal of Proteome Research 9(12): 6595-6604. https://doi.org/10.1021/pr1007834

Jahan M S, Shu S, Wang Y, Chen Z, He M, Tao M, Sun J \& Guo S (2019). Melatonin alleviates heat-induced damage of tomato seedlings by balancing redox homeostasis and modulating polyamine and nitric oxide biosynthesis. BMC Plant Biology 19(1): 1-16

https://doi.org/10.1186/s12870-019-1992-7

Jain M, Mathur G, Koul S \& Sarin N (2001). Ameliorative effects of proline on salt stress-induced lipid peroxidation in cell lines of groundnut (Arachis hypogaea L.). Plant Cell Reports 20(5): 463-468. https://doi.org/10.1007/s002990100353

Ju Y L, Yue X F, Zhao X F, Zhao H \& Fang Y L (2018). Physiological, micro-morphological and metabolomic analysis of grapevine (Vitis vinifera L.) leaf of plants under water stress. Plant Physiology and Biochemistry 130: 501-510. https://doi.org/10.1016/j.plaphy.2018.07.036

Karimi S, Yadollahi A, Nazari-Moghadam R, Imani A \& Arzani K (2012). In vitro screening of almond (Prunus dulcis (Mill.) genotypes for drought tolerance. J Biol Environ Sci 6(18): 263-270

Karuppanapandian T, Moon J C, Kim C, Manoharan K \& Kim W (2011). Reactive oxygen species in plants: their generation, signal transduction, and scavenging mechanisms. Australian Journal of Crop Science 5(6): 709. https://doi.org/ 10.3316/informit.282079847301776

Kaya A \& Doganlar Z B (2019). Melatonin improves the multiple stress tolerance in pepper (Capsicum annuum). Scientia Horticulturae 256: 108509. https://doi.org/10.1016/j.scienta.2019.05.036

Kaynak L \& Ersoy N (1997). General properties and usage areas of plant growth regulators, Akd. Univ. Zir. Fac. Journal 10: $223-236$ (In Turkish).

Kocacaliskan I (2008). Plant Physiology. Nobel Publications Distribution, Science and Biology Publications Series, 316 (In Turkish).

Korkmaz A, Demir O, Kocacinar F \& Cuci Y (2016). Increasing tolerance to cold stress with foliar melatonin applications in pepper seedlings. Journal of Agriculture and Nature 19(3): 348-354 (In Turkish).

Li J, Yang Y, Sun K, Chen Y, Chen X \& Li X (2019). Exogenous melatonin enhances cold, salt and drought stress tolerance by improving antioxidant defense in tea plant (Camellia sinensis (L.) O. Kuntze). Molecules 24(9): 1826. https://doi.org/ 10.3390/molecules24091826

Lichtenthaler H K \& Wellburn A R (1983). Determinations of total carotenoids and chlorophylls a and b of leaf extracts in different solvents. Botanisches Institutder Univeristat, Kaiserstran ße 12, Postfach pp. 591-592. https://doi.org/10.1042/BST0110591

Lim S H, \& Choi C I (2019). Pharmacological properties of Morus nigra L. (black mulberry) as a promising nutraceutical resource. Nutrients 11(2): 437. https://doi.org/ 10.3390/nu11020437

Lin Y, Fan L, Xia X, Wang Z, Yin Y, Cheng Y \& Li Z (2019). Melatonin decreases resistance to postharvest green mold on citrus fruit by scavenging defense-related reactive oxygen species. Postharvest Biology and Technology 153: 21-30. https://doi.org/10.1016/j.postharvbio.2019.03.016

Liu R, Shi H, WangY, Chen S, Deng J, Liu Y, Li S \& Chan Z (2014). Comparative physiological analysis of lotus (Nelumbo nucifera) cultivars in response to salt stress and cloning of NnCIPK genes. Scientia Horticulturae 173: 29-36. https://doi.org/ 10.1016/j.scienta.2014.04.032

Liu J, Wang W, Wang L \& Sun Y (2015). Exogenous melatonin improves seedling health index and drought tolerance in tomato. Plant Growth Regulation 77: 317-326. https://doi.org/10.1007/s10725-015-0066-6

Luck H (1963). Catalase: In: Methods of Enzymatic Analysis edited by HU. https://doi.org/10.1016/B978-0-12-395630-9.50158-4

MacAdam J W, Nelson C J \& Sharp R E (1992). Peroxidase activity in the leaf elongation zone of tall fescue: I. Spatial distribution of ionically bound peroxidase activity in genotypes differing in length of the elongation zone. Plant Physiology 99(3): 872-878. https://doi.org/10.1104/pp.99.3.872

Marchin R M, Ossola A, Leishman M R \& Ellsworth D S (2020). A simple method for simulating drought effects on plants. Frontiers in Plant Science 10: 1715. https://doi.org/10.3389/fpls.2019.01715

Marshall J G, Rutledge R G, Blumwald E \& Dumbroff E B (2000). Reduction in turgid water volume in jack pine, white spruce and black spruce in response to drought and paclobutrazol. Tree Physiology 20(10): 701-707. https://doi.org/ 10.1093/treephys/20.10.701

McCord J M \& Fridovich I (1969). Superoxide dismutase: An enzymic function for erytreoeuprein (Hemoeuprein). J. Biol. Chem 244: 22 6049- 6055

Mehta M \& Kumar A (2021). Nutrient composition, phytochemical profile and antioxidant properties of Morus nigra: A Review. International Journal of Innovative Science and Research Technology 6(2): 424-432 
Michel F B (1983). Evaluation of the water potentials of solutions of polyethylene glycol 8000 both in the absence and presence of other solutes. Plant Physiol 72: 66-70. https://doi.org/10.1104/pp.72.1.66

Moustafa-Farag M, Almoneafy A Mahmoud A, Elkelish A, Arnao MB, Li L \& Ai S (2020). Melatonin and its protective role against biotic stress impacts on plants. Biomolecules 10(1): 54. https://doi.org/10.3390/biom10010054

Murashige T \& Skoog F (1962). A revised medium for rapid growth and bioassays with tobacco tissue cultures. Physiol Plant 15: $473-497$. https://doi.org/10.1111/j.1399-3054.1962.tb08052.x

Nakano Y \& Asada K (1981). Hydrogen peroxide is scavenged by ascorbate-specific peroxidase in spinach chloroplasts. Plant and Cell Physiology 22(5): 867-880. https://doi.org/10.1093/oxfordjournals.pcp.a076232

Pandey N, Iqbal Z, Pandey BK \& Sawant SV (2017). Phytohormones and drought stress: plant responses to transcriptional regulation. Mechanism of plant hormone signaling under stress. John Wiley \& Sons, Hoboken, New Jersey, United States 477-504. https://doi.org/10.3389/fpls.2016.00434

Peters J L, Castillo F J \& Heath R L (1989). Alteration of extracellular enzymes in pinto bean leaves upon exposure to air pollutants, ozone and sulfur dioxide. Plant Physiology 89(1): 159-164. https://doi.org/10.1104/pp.89.1.159

Poeggeler B, Thuermann S, Dose A, Schoenke M, Burkhardt S \& Hardeland R (2002). Melatonin's unique radical scavenging properties-roles of its functional substituents as revealed by a comparison with its structural analogs. Journal of Pineal Research 33(1): 20-30. https://doi.org/10.1034/j.1600-079x.2002.01873.x

Posmyk M M \& Janas K M (2009). Melatonin in plants. Acta Physiologiae Plantarum 31(1): 1. https://doi.org/10.1007/s11738-008-0213-z

Qiao Y, Yin L, Wang B, Ke Q, Deng X \& Wang S (2019). Melatonin promotes plant growth by increasing nitrogen uptake and assimilation under nitrogen deficient condition in winter wheat. Plant Physiology and Biochemistry 139: 342-349. https://doi.org/10.1016/j.plaphy.2019.03.037

Reiter R J (1991). Pineal melatonin: cell biology of its synthesis and of its physiological interactions. Endocrine Reviews 12(2): 151-180. https://doi.org/10.1210/edrv-12-2-151

Rostami A A \& Rahemi M (2013). Responses of caprifig genotypes to water stress and recovery. Journal of Biological \& Environmental Sciences 7(21): 131-139

Rouhi V, Samson R, Lemeur R \& Van Damme P (2006). Stomatal resistance under drought stress conditions induced by PEG 6000 on wild almond. Communications in Agricultural and Applied Biological Sciences 71(1): 269

Sairam R K \& Saxena D C (2000). Oxidative stress and antioxidants in wheat genotypes: possible mechanism of water stress tolerance. Journal of Agronomy and Crop Science 184(1): 55-61. https://doi.org/10.1046/J.1439-037X.2000.00358

Sanchez F J, De Andres E F, Tenorio J L \& Ayerbe L (2004). Growth of epicotyls, turgor maintenance and osmotic adjustment in pea plants (Pisum sativum L.) subjected to water stress. Field Crops Research 86(1): 81-90. https://doi.org/10.1016/S0378-4290(03)00121-7

Santos C V (2004). Regulation of chlorophyll biosynthesis and degradation by salt stress in sunflower leaves. Scientia Horticulturae 103(1): 93-99. https://doi.org/ 10.1016/j.scienta.2004.04.009

Sarker U \& Oba S (2018). Drought stress effects on growth, ROS markers, compatible solutes, phenolics, flavonoids, and antioxidant activity in Amaranthus tricolor. Applied Biochemistry and Biotechnology 186(4): 999-1016. https://doi.org/ 10.1007/s12010-018-2784-5

Sekhar K M, Reddy K S \& Reddy A R (2017). Amelioration of drought-induced negative responses by elevated $\mathrm{CO}_{2}$ in field grown short rotation coppice mulberry (Morus spp.), a potential bio-energy tree crop. Photosynthesis Research 132(2): 151-164. https://doi.org/10.1007/s11120-017-0351-5

Sharma A, Wang J, Xu D, Tao S, Chong S, Yan D, Li Z, Yuan H \& Zheng B (2020). Melatonin regulates the functional components of photosynthesis, antioxidant system, gene expression, and metabolic pathways to induce drought resistance in grafted Carya cathayensis plants. Science of the Total Environment 713: 136675. https://doi.org/10.1016/j.scitotenv.2020.136675

Shereefa L A H \& Kumaraswamy M (2016). Reactive oxygen species and ascorbate-glutathione interplay in signaling and stress responses in Sesamum orientale L. against Alternaria sesami (Kawamura) Mohanty and Behera. Journal of the Saudi Society of Agricultural Sciences 15(1): 48-56. https://doi.org/10.1016/j.jssas.2014.04.007

Slinkard K \& Singleton V L (1977). Total phenol analysis: automation and comparison with manual methods. American Journal of Enology and Viticulture 28(1): 49-55

Smirnoff N (1993). The role of active oxygen in the response of plants to water deficit and desiccation. New Phytologist 125(1): 27-58. https://doi.org/10.1111/j.1469-8137.1993.tb03863.x

Upadhyaya H, Khan M H \& Panda S K (2007). Hydrogen peroxide induces oxidative stress in detached leaves of Oryza sativa L. Gen Appl Plant Physiol 33(1-2): 83-95

Vijayan K, Tikader A, Weiguo Z, Nair C V, Ercisli S \& Tsou C H (2011). Morus. In Wild Crop Relatives: Genomic and Breeding Resources, pp. 75-95. Springer, Berlin, Heidelberg.

Volkert M R, Loewen P C, Switala J, Crowley D \& Conley M (1994). The delta (argF-lacZ) 205 (U169) deletion greatly enhances resistance to hydrogen peroxide in stationary-phase Escherichia coli.Journal of Bacteriology 176(5): 1297-1302. https://doi.org/10.1128/jb.176.5.1297-1302.1994

Wang W, Vinocur B, Shoseyov O \& Altman A (2004). Role of plant heat-shock proteins and molecular chaperones in the abiotic stress response. Trends in Plant Science 9(5): 244-252. https://doi.org/10.1016/j.tplants.2004.03.006

Wang Y, Reiter R J \& Chan Z (2017). Phytomelatonin: a universal abiotic stress regulator. Journal of Experimental Botany 69(5): 963-974. https://doi.org/10.1093/jxb/erx473

Wang Z, Tang C, Xiao G, Dai F, Lin S, Li Z \& Luo G (2021). Comparison of free and bound phenolic compositions and antioxidant activities of leaves from different mulberry varieties. BMC Chemistry 15(1): 1-15 https://doi.org/10.1186/s13065-021-00747-0

Xia H, Shen Y, Shen T, Wang X, Zhang X, Hu P \& Deng Q (2020). Melatonin accumulation in sweet cherry and its influence on fruit quality and antioxidant properties. Molecules 25(3): $753 \mathrm{https} / / /$ doi.org/10.3390/molecules25030753

Zhang L, Jia J, Xu Y, Wang Y, Hao J \& Li T (2012). Production of transgenic Nicotiana sylvestris plants expressing melatonin synthetase genes and their effect on UV-B-induced DNA damage. In Vitro Cellular \& Developmental Biology-Plant 48(3): 275-282 https://doi.org/10.1007/s11627-011-9413-0

Zhang N, Sun Q, Li H, Li X, Cao Y, Zhang H, Li S, Zhang L, Qi Y \& Zhao B (2016). Melatonin improved anthocyanin accumulation by regulating gene expressions and resulted in high reactive oxygen species scavenging capacity in cabbage. Frontiers in Plant Science 7: 197 https://doi.org/10.3389/fpls.2016.00197 
Zhao H J \& Tan J F (2005). Role of calcium ion in protection against heat and high irradiance stress-induced oxidative damage to photosynthesis of wheat leaves. Photosynthetica 43(3): 473-476 https://doi.org/10.1007/s11099-005-0076-0

Zheng H, Zhang X, Ma W, Song J, Rahman S U, Wang J \& Zhang Y (2017a). Morphological and physiological responses to cyclic drought in two contrasting genotypes of Catalpa bungei. Environmental and Experimental Botany 138: 77-87 https://doi.org/10.1016/j.envexpbot.2017.02.016

Zheng X, Tan D X, Allan A C, Zuo B, Zhao Y, Reiter R J, Wang L, Wang Z, Guo Y, Zhou J, Shan D, Li Q, Han Z \& Zhou J (2017b). Chloroplastic biosynthesis of melatonin and its involvement in protection of plants from salt stress. Sci. Rep 7(1): 1-12 https://doi.org/10.1038/srep41236

Zhu J, Li Z, Kang H \& Fan Y (2005). Effects of polyethylene glycol (PEG)-simulated drought stress on Pinus sylvestris var. mongolica seed germination on sandy land. Ying Yong Sheng Tai Xue Bao. The Journal of Applied Ecology 16(5): 801-804

(C) 2022 by the author(s). Published by Ankara University, Faculty of Agriculture, Ankara, Turkey. This is an Open Access article distributed under the terms and conditions of the Creative Commons Attribution (CC BY) license (http://creativecommons.org/licenses/by/4.0/), which permits unrestricted use, distribution, and reproduction in any medium, provided the original work is properly cited. 